\title{
PREPARATION OF MAGNETIC-ZnO NANOCOMPOSITE BY HIGH ENERGY MILLING METHOD FOR METHYL ORANGE DEGRADATION
}

\section{(PEMBUATAN NANOKOMPOSIT MAGNET-ZnO DENGAN METODA HIGH ENERGY MILLING UNTUK DEGRADASI METHYL ORANGE)}

\author{
Didin S. Winatapura, Siti Wardiyati, and Adel Fisli \\ Pusat Sains dan Teknologi Bahan Maju - Badan Tenaga Nuklir Nasional \\ Gd. 42 Kawasan Puspiptek, Serpong, Tangerang 15314 - Indonesia. \\ E-mail: didinsw@batan.go.id
}

Received: 8 Juli 2016; revised: 18 September 2016; accepted: 29 September 2016

\begin{abstract}
A magnetic $\mathrm{Fe}_{3} \mathrm{O}_{4} / \mathrm{ZnO}$ nanocomposite (NCs) was prepared by a high energy milling (HEM) method. In the present study, the $\mathrm{ZnO}$ catalyst was prepared through two ways. The $\mathrm{ZnO}$ was synthesized by coprecipitation method $(\mathrm{ZnO}(\mathrm{S}))$, and $\mathrm{ZnO}$ directly used a commercial product ( $\mathrm{nnO}(\mathrm{Ald})$ ). The prepared NCs were characterized using X-ray diffraction (XRD), vibrating sample magnetometer (VSM), Fourier transform infrared (FTIR), transmission electron microscope (TEM), and UV-Vis spectrophotometer. The XRD refinement indicates that $\mathrm{Fe}_{3} \mathrm{O}_{4}$ nanoparticle (NP) is a single phase and well indexed to cubic spinal structured magnetite. The $\mathrm{Fe}_{3} \mathrm{O}_{4} / \mathrm{ZnO}(\mathrm{S})$ and $\mathrm{Fe}_{3} \mathrm{O}_{4} / \mathrm{ZnO}$ (Ald) NCs are consisted of $\mathrm{Fe}_{3} \mathrm{O}_{4}$ and $\mathrm{ZnO}$ phases. The VSM result show that $\mathrm{Fe}_{3} \mathrm{O}_{4} \mathrm{NP}, \mathrm{Fe}_{3} \mathrm{O}_{4} / \mathrm{ZnO}\left(\mathrm{S}\right.$ ), and $\mathrm{Fe}_{3} \mathrm{O}_{4} / \mathrm{ZnO}$ (Ald) NCs possess super-paramagnetic properties with saturation magnetization $\left(\mathrm{M}_{\mathrm{s}}\right)$ is $102 \mathrm{emu}^{-1} \mathrm{~g}^{-1} 28 \mathrm{emu}^{-1}$ and $26 \mathrm{emu} . \mathrm{g}^{-1}$, respectively. The TEM observation shows that the average diameter of $\mathrm{Fe}_{3} \mathrm{O}_{4}$ is approximately $15 \mathrm{~nm}$, while the thickness both of $\mathrm{ZnO}$ shell is ranging $20 \mathrm{~nm}-50 \mathrm{~nm}$. The average diameter of $\mathrm{TiO}_{2} \mathrm{P} 25$ particle as catalyst was observed about $20 \mathrm{~nm}$. The photocatalytic activity of catalysts were evaluated based on the degradation of methyl orange (MO) dye solution. The result shows that at $\mathrm{pH}=7$, the $\mathrm{Fe}_{3} \mathrm{O}_{4} / \mathrm{ZnO}$ (Ald) $\mathrm{NC}$ can degrade the pollutant in $\mathrm{MO}$ dye solution to $99 \%$, where as at $\mathrm{pH}=3$, the catalyst $\mathrm{TiO}_{2} \mathrm{P} 25$ degrade only $96 \%$.
\end{abstract}

Keywords: $\mathrm{Fe}_{3} \mathrm{O}_{4} / \mathrm{ZnO}$ nanocomposite, High energy milling, Degradation, Methyl orange, Photo-catalytic

\begin{abstract}
ABSTRAK
Nanokomposit magnet $\mathrm{Fe}_{3} \mathrm{O}_{4} / \mathrm{ZnO}$ (NK) dibuat menggunakan metoda High Energy Milling (HEM). Pada penelitian kali ini, katalis ZnO disiapkan melalui dua metode. ZnO dibuat dengan metode kopresipitasi ZnO (S), dan katalis $\mathrm{ZnO}$ dipakai langsung dari produk komersial ( $\mathrm{ZnO}$ (Ald)). NK yang dihasilkan dikarakterisasi menggunakan $X$-ray diffraction (XRD), vibrating sample magnetometer (VSM), Fourier transform infrared (FTIR), transmission electron microscope (TEM) dan UV-Vis spectrophotometer. Hasil refinement XRD memperlihatkan bahwa $\mathrm{Fe}_{3} \mathrm{O}_{4}$ berfase tunggal dan terindeks baik untuk magnet berstruktur spinel kubik. $\mathrm{NK} \mathrm{Fe}_{3} \mathrm{O}_{4} / \mathrm{ZnO}(\mathrm{S})$ dan $\mathrm{Fe}_{3} \mathrm{O}_{4} / \mathrm{ZnO}$ (Ald) tersusun dari fase $\mathrm{Fe}_{3} \mathrm{O}_{4}$ dan $\mathrm{ZnO}$. Hasil pengukuran sampel dengan VSM menunjukkan bahwa $\mathrm{Fe}_{3} \mathrm{O}_{4}, \mathrm{Fe}_{3} \mathrm{O}_{4} / \mathrm{ZnO}$ (S) dan $\mathrm{Fe}_{3} \mathrm{O}_{4} / \mathrm{ZnO}$ (Ald) berkelakuan superparamagnetic dengan menghasilkan magnet saturasi $\left(\mathrm{M}_{\mathrm{s}}\right)$ masing-masing sebesar $102 \mathrm{emu}^{-1} \mathrm{~g}^{-1}, 28 \mathrm{emu} . \mathrm{g}^{-1}$ dan 26 emu. $\mathrm{g}^{-1}$. Hasil pengamatan sampel dengan TEM menunjukkan bahwa diameter rata-rata $\mathrm{Fe}_{3} \mathrm{O}_{4}$ sekitar $15 \mathrm{~nm}$, sedangkan ketebalan lapisan $\mathrm{ZnO}$ keduanya berkisar $20 \mathrm{~nm}-50 \mathrm{~nm}$. Ukuran diameter rata-rata partikel $\mathrm{TiO}_{2} \mathrm{P} 25$ teramati sekitar $20 \mathrm{~nm}$. Aktivitas fotokatalik dievaluasi dengan mendegradasi larutan methyl orange (MO). Hasil pengujian menunjukkan bahwa pada $\mathrm{pH}=7, \mathrm{Fe}_{3} \mathrm{O}_{4} / \mathrm{ZnO}$ (Ald) mampu mendegradasi larutan zat warna $M O$ hingga $99 \%$, sedangkan pada $\mathrm{pH}=3$, katalis $\mathrm{TiO}_{2} \mathrm{P} 25$ hanya mampu mendegradasi $96 \%$.
\end{abstract}

Kata kunci: Nanokomposit $\mathrm{Fe}_{3} \mathrm{O}_{4} / \mathrm{ZnO}$, High energy milling, Degradasi, Methyl orange, Fotokatalitik

\section{INTRODUCTION}

Metal oxide semiconductor photocatalysts have been extensively studied in the fields of environmental purification. Among the various oxide semiconductor photo-catalysts zinc oxide $(\mathrm{ZnO})$, and titanium dioxide $\left(\mathrm{TiO}_{2}\right)$ from the commercial Degussa product P25 are widely used as materials for photo-catalytic processes, because of its high photosensitivity, 
and environmentally friendly nature. $\mathrm{ZnO}$ and $\mathrm{TiO}_{2}$ P25 have proven to be the most suitable materials for removing pollutants from the water with their high surface-to-volume ratio, high photosensitivity, good quantum efficiency, and non-toxic to the nature (Abdollahi et al. 2012; Álvarez et al. 2010). However, a main problem in industrial application of $\mathrm{ZnO}$ and $\mathrm{TiO}_{2} \quad \mathrm{P} 25$ nanoparticles in slurry reactor system is the difficulties encountered in recollection of the nanoparticles from the treated waters. The separation step such as filtration is not enough to prevent the possible large scale loss and the potential secondary pollution caused by the loss $\mathrm{ZnO}$ and $\mathrm{TiO}_{2}$ P25 nanoparticles (Abdollahi et al. 2012; Ahadpour Shal and Jafari 2014; Xu and Li 2014).

Recently, magnetically separable photocatalysts of the $\mathrm{Fe}_{3} \mathrm{O}_{4} / \mathrm{ZnO} \mathrm{NCs}$ have attracted attention because of their scientific and technological importance in the environmental purification (Feng et al. 2014; Nikazar et al. 2014). In this case, both the $\mathrm{Fe}_{3} \mathrm{O}_{4}$ magnetic core and the $\mathrm{ZnO}$ shell are of interest. The incorporation of $\mathrm{Fe}_{3} \mathrm{O}_{4}$ magnetic core into the semiconductor $\mathrm{ZnO}$ possesses the property not only of high surface area to volume ratio but also the magnetic photo-catalysts have dual functions. $\mathrm{Fe}_{3} \mathrm{O}_{4}$ magnetic component can be easily and effectively collected the catalysts with the help of a magnetic field, and the photocatalytic properties of $\mathrm{ZnO}$ shell can eliminate the organic pollutants in the wastewater.

Several methods have been already established for the preparation of magnetic photo-catalyst and their photo-catalytic properties. Nikazar et al. (2014) used precipitation method for preparation of $\mathrm{Fe}_{3} \mathrm{O}_{4} / \mathrm{ZnO} \mathrm{NCs}$, and Feng et al. (2014), fabricated the $\mathrm{Fe}_{3} \mathrm{O}_{4} / \mathrm{ZnO}$ by dehydrating zinc acetate in the present of $\mathrm{Fe}_{3} \mathrm{O}_{4} \mathrm{NPs}$ in diethylene glycol. Both of $\mathrm{Fe}_{3} \mathrm{O}_{4} / \mathrm{ZnO} \mathrm{NPs}$ exhibited a high activity photo-catalytic for phenol degradation.

Recently, Winatapura et al., (2016) have performed the $\mathrm{Fe}_{3} \mathrm{O}_{4} / \mathrm{ZnO}$ using $\mathrm{Zn}\left(\mathrm{CH}_{3} \mathrm{COO}\right)_{2} \cdot 2 \mathrm{H}_{2} \mathrm{O}$ precursor to make $\mathrm{ZnO}$ nanoparticles for methylene blue degradation.

In this work is focused that the magnetic $\mathrm{Fe}_{3} \mathrm{O}_{4} / \mathrm{ZnO} \mathrm{NCs}$ were produced by a mechanochemical activation using high energy milling (HEM) process for methyl orange (MO) degradation. It is well known that the mechanochemical or the activation of chemical reactions by mechanical energy can lead many applications, it is from waste processing to the production of advanced materials and enhanced mechanical properties (Giwa et al. 2012; Iwasaki et al. 2010).
The $\mathrm{ZnO} \mathrm{NP}$ as a catalyst is obtained in two ways. Firstly, $\mathrm{ZnO}$ is made from $\mathrm{ZnCl}_{2} \cdot 6 \mathrm{H}_{2} \mathrm{O}$ precursor using coprecipitation method. Secondly, the $\mathrm{ZnO}$ was taken from a commercial product (Sigma-Aldrich) without further purification. The weight percent ratio between $\mathrm{ZnO}$ and $\mathrm{Fe}_{3} \mathrm{O}_{4}$ is arranged of $1: 4$. The obtained $\mathrm{Fe}_{3} \mathrm{O}_{4} / \mathrm{ZnO} \mathrm{NCs}$ were annealed at $550^{\circ} \mathrm{C}$ for 2 hours, and then characterized using X-rays diffractometer, vibrating sample magnetometer, transmission electron microscope, and UV-Vis spectrophotometer. The photo-catalytic efficiency of $\mathrm{Fe}_{3} \mathrm{O}_{4} / \mathrm{ZnO} \mathrm{NCs}$ at different $\mathrm{pH}$ solution of $\mathrm{MO}$ dye photodegradation was reported. These results were compared with the $\mathrm{TiO}_{2}$ catalyst from commercial Degussa product P25 (Germany). In the frame of this research $\mathrm{TiO}_{2} \mathrm{P} 25$ was used as comparative material.

\section{MATERIALS AND METHOD}

\section{Materials}

$\mathrm{FeCl}_{3} \cdot 6 \mathrm{H}_{2} \mathrm{O}, \quad \mathrm{FeCl}_{2} \cdot 4 \mathrm{H}_{2} \mathrm{O}, \mathrm{HCl}$, Methyl orange (MO), $\mathrm{NaOH}, \mathrm{NH}_{4} \mathrm{OH}$ and $\mathrm{ZnCl}_{2} \cdot 6 \mathrm{H}_{2} \mathrm{O}$ are Merck products. Commercial $\mathrm{ZnO}$ ( $\geq 99.0 \%$ ) powder is Sigma Aldrich and $\mathrm{TiO}_{2}$ from commercial Degussa product P25 (Germany).

\section{Methods}

The $\mathrm{Fe}_{3} \mathrm{O}_{4}$ NPs were synthesized with coprecipitation method using iron (III) chloride, $\mathrm{FeCl}_{3} \cdot 6 \mathrm{H}_{2} \mathrm{O}$ and iron (II) chloride, $\mathrm{FeCl}_{2} \cdot 4 \mathrm{H}_{2} \mathrm{O}$ with molar ratio of $2: 1$ according to the method used by Winatapura et al. (2014) with modification. The synthesis was performed at $70^{\circ} \mathrm{C}$ using the $1-\mathrm{M} \mathrm{NaOH}$ and $\mathrm{NH}_{4} \mathrm{OH}(25 \%)$ solution as precipitate agents. The chemical reaction of this process is written as follows (Ahadpour Shal and Jafari 2014):

$$
\begin{array}{cc}
\mathrm{Fe}^{+2}+2 \mathrm{Fe}^{+3}+8 \mathrm{OH} & \mathrm{Fe}(\mathrm{OH})_{2} 2 \mathrm{Fe}(\mathrm{OH})_{3} \rightarrow \\
\mathrm{Fe}_{3} \mathrm{O}_{4} \downarrow+4 \mathrm{H}_{2} \mathrm{O} & \ldots \ldots \ldots \ldots \ldots
\end{array}
$$

The ZnO NPs was synthesis using coprecipitation method from $\mathrm{ZnCl}_{2} \cdot 6 \mathrm{H}_{2} \mathrm{O}$ raw materials. In this work, 1-M of $\mathrm{NaOH}$ solution was added drop wise to $\mathrm{ZnCl}_{2} \cdot 6 \mathrm{H}_{2} \mathrm{O}$ at $80{ }^{\circ} \mathrm{C}$ until $\mathrm{pH}=12$. The reaction can be written as:

$$
\mathrm{Zn}^{+2}+2 \mathrm{OH} \rightarrow \mathrm{ZnO}+\mathrm{H}_{2} \mathrm{O}
$$

The white precipitate was collected, purified with water and dried at $100^{\circ} \mathrm{C}$.

The preparation of $\mathrm{Fe}_{3} \mathrm{O}_{4} / \mathrm{ZnO} \mathrm{NCs}$ was conducted by HEM (Certi-Prep $8000 \mathrm{M}$ machine). The $\mathrm{Fe}_{3} \mathrm{O}_{4} \mathrm{NPs}$ and $\mathrm{ZnO}$ powders (with $1: 4$ weights ratio) were mixed in a 
Tungsten Carbide vial and milling for $10 \mathrm{~h}$. The weight ratio of $\mathrm{Fe}_{3} \mathrm{O}_{4} / \mathrm{ZnO} \mathrm{NCs}$ and agate balls was arranged of $1: 5$. The $\mathrm{Fe}_{3} \mathrm{O}_{4} / \mathrm{ZnO}$ (S) NCs was annealed at $550{ }^{\circ} \mathrm{C}$ for $2 \mathrm{~h}$. This sample was labeled by $\mathrm{Fe}_{3} \mathrm{O}_{4} / \mathrm{ZnO}(\mathrm{S})$. The same procedure was then repeated for preparation of $\mathrm{Fe}_{3} \mathrm{O}_{4}$ and $\mathrm{ZnO}$ commercial product (Sigma Aldrich), and labeled with $\mathrm{Fe}_{3} \mathrm{O}_{4} / \mathrm{ZnO}$ (Ald). X-ray diffraction (XRD) patterns of the NCs were collected on a Pan-Analytical diffractometer with CuK $\alpha$ radiation $(\lambda=0.154 \mathrm{~nm})$. The XRD data was analyzed using general structure analysis system (GSAS) (Larson and Von Dreele 2004). The magnetization of the sample was measured using a VSM (Oxford 1,2T). TEM images of NCs were obtained with a transmission electron microscope (JEOL JEM-1400) at an accelerating voltage of $120 \mathrm{kV}$.

Photo-catalytic degradation of $\mathrm{MO}$ was performed in a slurry batch reactor which consisted of cylindrical beaker glass, magnetic stirrer and an UV-pen Ray 100 watt, $\lambda=356 \mathrm{~nm}$ (Model: UVP Pen Ray 90-0016-01), located at the center of the reactor. The distance between an UV-pen lamp and $\mathrm{MO}$ dye solution was arranged of about $5 \mathrm{~cm}$. In all experiments, $100 \mathrm{~mL} \mathrm{MO}$ dye in water solution of $30 \mathrm{ppm}$ concentration was adjusted to $\mathrm{pH} 3$ and $\mathrm{pH} 7$. Then $0.1 \mathrm{~g}$ of each $\mathrm{Fe}_{3} \mathrm{O}_{4} / \mathrm{ZnO}$ (S) and $\mathrm{Fe}_{3} \mathrm{O}_{4} / \mathrm{ZnO}$ (Ald) NCs catalyst is added, and the mixture was stirred magnetically to obtain homogeneous suspension. Before irradiation, the reaction mixture was put in darkness for $3 \mathrm{~h}$ to achieve maximum adsorption of the $\mathrm{MO}$ onto the catalyst surface. After $3 \mathrm{~h}$, a sample was taken and photocatalyst particles were separated using a magnetic bar. The $455 \mathrm{~nm}$ of MO dye concentration remaining was determinated by UV-Vis spectrophotometer (Perkin-Elmer, Lambda 25) at a wavelength. These results are compared with $\mathrm{TiO}_{2} \mathrm{P} 25$ from the comemercial Degussa product (Sigma Aldrich).

\section{RESULTS AND DISCUSSION}

The refinement result of XRD pattern of the prepared $\mathrm{Fe}_{3} \mathrm{O}_{4} \mathrm{NP}$, synthesized zinc oxide, $\mathrm{ZnO}(\mathrm{S})$ and zinc oxide commercial product (Sigma Aldrich), ZnO (Ald) are shown in Figure 1. In the XRD pattern of the prepared $\mathrm{Fe}_{3} \mathrm{O}_{4} \mathrm{NP}$, all diffraction peaks are well indexed to cubic spinal structured magnetite and appear at Bragg angles $2 \theta \sim 30.23^{\circ}, 35.52^{\circ}, 43.03^{\circ}$, $53.14 \circ, 57.02 \circ, 62.54 \circ$ corresponding to Miller indices (220), (311), (400), (422), (511), (440), according to JCPDS file no. 19-0629. Based on the Figure 1(a), the prepared growth orientation of $\mathrm{Fe}_{3} \mathrm{O}_{4}$ lies along (311) crystallographic direction. It can be seen that the prepared $\mathrm{Fe}_{3} \mathrm{O}_{4}$ exhibit a single phase and no other peak associated with the impurity phase.

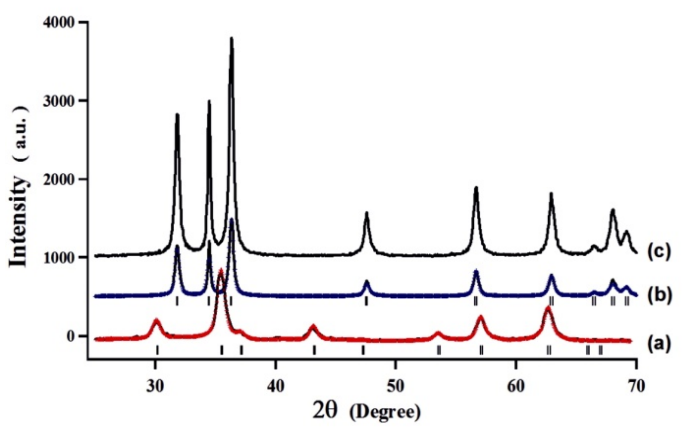

Figure 1. Refinement result of XRD pattern: (a) $\mathrm{Fe}_{3} \mathrm{O}_{4}$, (b) $\mathrm{ZnO}$ (S), and (c) ZnO (Ald) NPs

Fig. 1(b) and 1(c) show a refinement result of typical XRD pattern of prepared and the commercial zinc oxide, $\mathrm{ZnO}(\mathrm{S})$, and $\mathrm{ZnO}$ (Ald) NPs, respectively. Based on the Figure 1(b) and $1(c)$, the strong sharp peaks indicate that the $\mathrm{ZnO}$ (S) and $\mathrm{ZnO}$ (Ald) NPs are highly crystalline. The diffraction peaks of both $\mathrm{ZnO}$ are match with the standard data for a wurtzite structure (JPCDS 36-1451), and seemed at Bragg angles $2 \theta \sim 31.85^{\circ}, 34.45^{\circ}, 36.35^{\circ}$, $47.60^{\circ}, 66.70 \circ, 62.90 \circ$, 66.55॰, 68.05॰ 69.20。 related to Miller indices (100), (002), (101), (102), (110), (103), (200), (112), (201). It is apparent from Figure 1(b) and 1(c) that both $\mathrm{ZnO}$ preparation results and the commercial product showed a single phase. A preferred growth orientation lies along the (101) crystallographic direction at $2 \theta \sim 36.35^{\circ}$.

Figure 2 shows the refinement result of XRD $\mathrm{Fe}_{3} \mathrm{O}_{4} / \mathrm{ZnO}$ (S) and $\mathrm{Fe}_{3} \mathrm{O}_{4} / \mathrm{ZnO}$ (Ald) NCs produced very good quality of fitting with $\mathrm{R}$ factor is very small, and goodness of fit value $x^{2}$ (chisquared). It is seem that all the diffraction peaks can be readily indexed to $\mathrm{Fe}_{3} \mathrm{O}_{4}$ and $\mathrm{ZnO}$ phases. The diffraction peaks of $\mathrm{Fe}_{3} \mathrm{O}_{4}$ phase are indexed by " ", while peaks intensity of the $\mathrm{ZnO}$ phase that marked by "+". Some peaks of intensity enhancement are detected due to peak overlapping, as seen in Fig. 2. This is in a good agreement with work done by Feng et al. (2014).

Fig. 3 presents magnetization $\mathrm{M}$ curve of prepared $\mathrm{Fe}_{3} \mathrm{O}_{4} \mathrm{NPs}$, before and after $\mathrm{ZnO}$ coating, versus applied field $\mathrm{H}$ between -10 and $+10 \mathrm{kOe}$ measured by VSM. The magnetization saturation $\left(\mathrm{M}_{\mathrm{s}}\right)$ value of $\mathrm{Fe}_{3} \mathrm{O}_{4} \mathrm{NPs}$ measured at room temperature exhibits an excellent magnetic saturation $\left(M_{s}\right)$ is around 102emu.g ${ }^{-1}$ (Fig. 3(a)). The magnetic property $\mathrm{Fe}_{3} \mathrm{O}_{4} \mathrm{NPs}$ is superparamagnetic behaviour with no coercivity due to their small size. The $\mathrm{M}_{\mathrm{s}}$ Value was observed around 93 and 65 emu.g ${ }^{-1}$ for $\mathrm{Fe}_{3} \mathrm{O}_{4}$ bulk and NPs, respectively (Wei et al. 2012). However, 
the $\mathrm{M}_{\mathrm{s}}$ Value of $\mathrm{Fe}_{3} \mathrm{O}_{4} \mathrm{NP}$ then reduces to 28.00emu.g ${ }^{-1}$ and $25.75 \mathrm{emu}^{-1}$ for $\mathrm{Fe}_{3} \mathrm{O}_{4} / \mathrm{ZnO}$ (Ald) and $\mathrm{Fe}_{3} \mathrm{O}_{4} / \mathrm{ZnO}(\mathrm{S})$, respectively. The molar ratio between $\mathrm{Fe}_{3} \mathrm{O}_{4}$ and $\mathrm{ZnO}$ was arranged of $1: 4$. It can be seen that the coating of $\mathrm{ZnO}$ did not change the super-paramagnetic properties of $\mathrm{Fe}_{3} \mathrm{O}_{4} \mathrm{NP}$. The reduction of the saturation magnetization results from the existence of nonmagnetic $\mathrm{ZnO}$ shell on the surface of $\mathrm{Fe}_{3} \mathrm{O}_{4}$ core NPs. The measurement result is displays in Table 1.

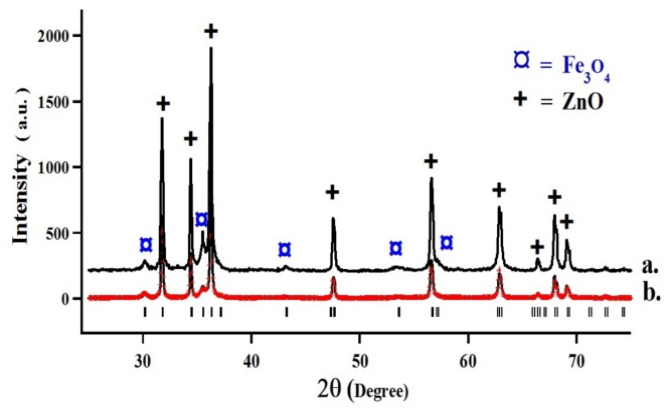

Figure 2. Refinement result of XRD pattern:

(a) $\mathrm{Fe}_{3} \mathrm{O}_{4} / \mathrm{ZnO}\left(\mathrm{S}\right.$ ), and (b) $\mathrm{Fe}_{3} \mathrm{O}_{4} / \mathrm{ZnO}$ (Ald) NCs

The TEM micrograph of prepared $\mathrm{Fe}_{3} \mathrm{O}_{4}$ $\mathrm{NPs}, \mathrm{Fe}_{3} \mathrm{O}_{4} / \mathrm{ZnO}$ (S) NCs, $\mathrm{Fe}_{3} \mathrm{O}_{4} / \mathrm{ZnO}$ (Ald) NCs, and $\mathrm{TiO}_{2} \mathrm{P} 25 \mathrm{Nps}$ are presented in Fig. 4. The most of aggregated $\mathrm{Fe}_{3} \mathrm{O}_{4}$ particles are spherical; with the average size of the most particles is nearly $15 \mathrm{~nm}$, as seen in Fig. $4 \mathrm{a}$. Fig. $4 \mathrm{~b}$ and $4 \mathrm{c}$ show TEM image of $\mathrm{Fe}_{3} \mathrm{O}_{4} / \mathrm{ZnO}(\mathrm{S})$ and $\mathrm{Fe}_{3} \mathrm{O}_{4} / \mathrm{ZnO}$ (Ald) NCs. It can be seen clearly that the whole $\mathrm{Fe}_{3} \mathrm{O}_{4} \mathrm{NPs}$ coated by the $\mathrm{ZnO}$ shell. The morphology of these $\mathrm{Fe}_{3} \mathrm{O}_{4} / \mathrm{ZnO} \mathrm{NCs}$ was generally the same which shows a coreshell like structures. The dark part (black colour) of the $\mathrm{Fe}_{3} \mathrm{O}_{4} / \mathrm{ZnO} \mathrm{NCs}$ is the $\mathrm{Fe}_{3} \mathrm{O}_{4}$ core and the $\mathrm{ZnO}$ shell is the light parts (grey colour), as it is seen in Fig. 4(b) and 4(c). The thickness of the $\mathrm{ZnO}$ shell in both of $\mathrm{Fe}_{3} \mathrm{O}_{4} / \mathrm{ZnO}$ (Ald) and $\mathrm{Fe}_{3} \mathrm{O}_{4} / \mathrm{ZnO}(\mathrm{S})$ is between $20-50 \mathrm{~nm}$. This result is in a good agreement with Choi et al. (2011), which the magnetic composite consist of nanoscale grains and has a super-paramagnetic behaviour. TEM image of $\mathrm{TiO}_{2}$ nanoparticles from commercial Degussa product P25 are shown in Fig. 4 (d). It is clear spherical and non homogenous structure can be seen in Fig. 4 (d) having diameter $\sim 20 \mathrm{~nm}$.

The photo-catalytic activity was expressed by means of the degradation efficiencies of methyl orange (MO) dye for different catalysts and condition ( $\mathrm{pH}=3$ and 7 ) are presented in Fig. 5 and 6.

This is due to the $\mathrm{pH}$ value of dye solution is an important parameter in photo-catalytic degradation reactions that are taking place on the surfaces of semiconductors. It determines the surface charge properties of the photocatalyst and the adsorption behaviour of pollutants.

Based on Fig 5 (a) - (d), the degradation rate of $\mathrm{MO}$ dye solution is obtained about $96 \%$, $80 \%, 70 \%$ and $2 \%$, respectively, for $\mathrm{TiO}_{2} \mathrm{P} 25$, $\mathrm{Fe}_{3} \mathrm{O}_{4} / \mathrm{ZnO}$ (Ald), $\quad \mathrm{Fe}_{3} \mathrm{O}_{4} / \mathrm{ZnO} \quad(\mathrm{S})$, and noncatalyst after 180 minutes UV-irradiation. The results were described in Table 1. Noncatalyst experiment was performed in the absence of any photo-catalysts, showed the absence of photo-degradation of $\mathrm{MO}$ under these reaction conditions. It can be seen that photo-catalytic efficiency of the $\mathrm{TiO}_{2} \mathrm{P} 25 \mathrm{NPs}$ is more suitable in acidic condition then $\mathrm{Fe}_{3} \mathrm{O}_{4} / \mathrm{ZnO}$ (Ald), $\mathrm{Fe}_{3} \mathrm{O}_{4} / \mathrm{ZnO}(\mathrm{S}) \mathrm{NCs}$ catalysts.

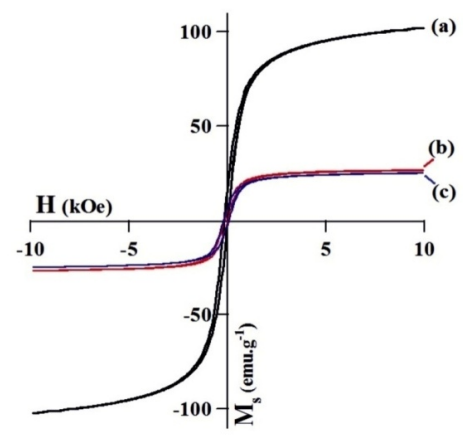

Figure 3. Magnetization curve of (a) $\mathrm{Fe}_{3} \mathrm{O}_{4} \mathrm{NPs}$, (b) $\mathrm{Fe}_{3} \mathrm{O}_{4} / \mathrm{ZnO}$ (Ald) and (c) $\mathrm{Fe}_{3} \mathrm{O}_{4} / \mathrm{ZnO}$ (S) NCs

Table 1. Parameters of degradation rate, apparent rate constant $\left(k_{a p p .}\right)$, and half life $\left(\mathrm{t}_{1 / 2}\right)$.

\begin{tabular}{lccccccc}
\hline \multicolumn{1}{c}{ Catalyst } & $\begin{array}{c}\mathrm{M}_{\mathrm{s}} \\
\left(\mathrm{emu} \cdot \mathrm{g}^{-1}\right)\end{array}$ & \multicolumn{2}{c}{ Deg. rate (\%) } & \multicolumn{2}{c}{$k_{\text {app }}\left(\mathrm{h}^{-1}\right)$} & \multicolumn{2}{c}{$\mathrm{t}_{1 / 2}(\mathrm{~h})$} \\
\hline & & $\mathrm{pH}=3$ & $\mathrm{pH}=7$ & $\mathrm{pH}=3$ & $\mathrm{pH}=7$ & $\mathrm{pH}=3$ & $\mathrm{pH}=7$ \\
$\mathrm{Blank}_{\mathrm{TiO}_{2} \mathrm{P} 25}$ & - & 2 & 3 & - & - & - & - \\
$\mathrm{Fe}_{3} \mathrm{O}_{4} / \mathrm{ZnO}$ (S) & - & 96 & 88 & 0.8732 & 0.7675 & 0.7938 & 0.6700 \\
$\mathrm{Fe}_{3} \mathrm{O}_{4} / \mathrm{ZnO}$ (Ald) & 26.00 & 70 & 96 & 0.3675 & 1.0337 & 1.8861 & 0.6705 \\
$\mathrm{Fe}_{3} \mathrm{O}_{4}$ & 28.00 & 80 & 99 & 0.4557 & 1.3040 & 1.5211 & 0.5315 \\
\hline
\end{tabular}



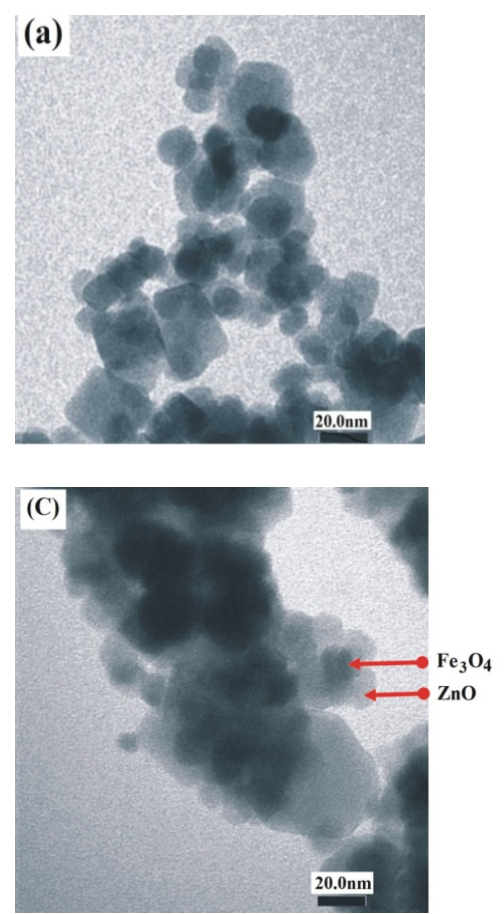
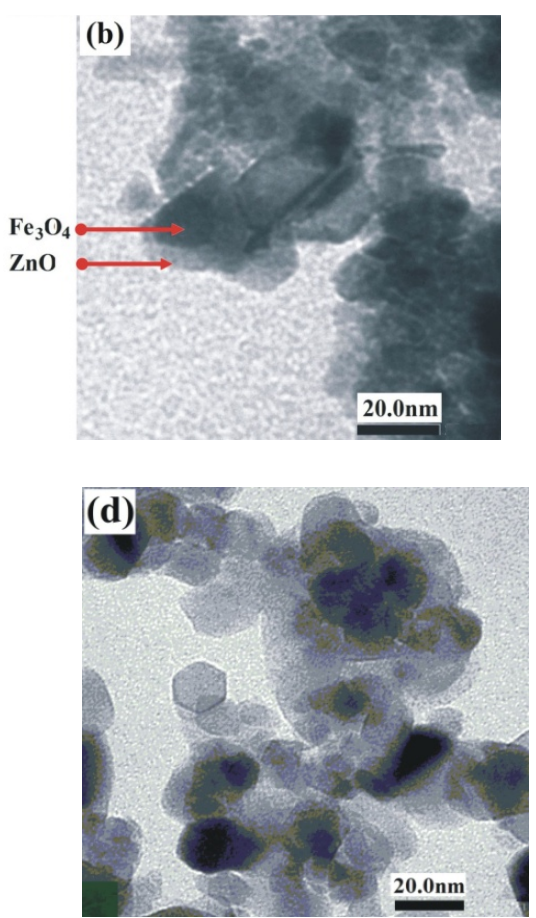

Figure 4. TEM micrograph of (a) $\mathrm{Fe}_{3} \mathrm{O}_{4} \mathrm{NPs}$, (b) $\mathrm{Fe}_{3} \mathrm{O}_{4} / \mathrm{ZnO}$ (S), and (c) $\mathrm{Fe}_{3} \mathrm{O}_{4} / \mathrm{ZnO}$ (Ald) NCs, and (d) $\mathrm{TiO}_{2}$ P25 NPs.

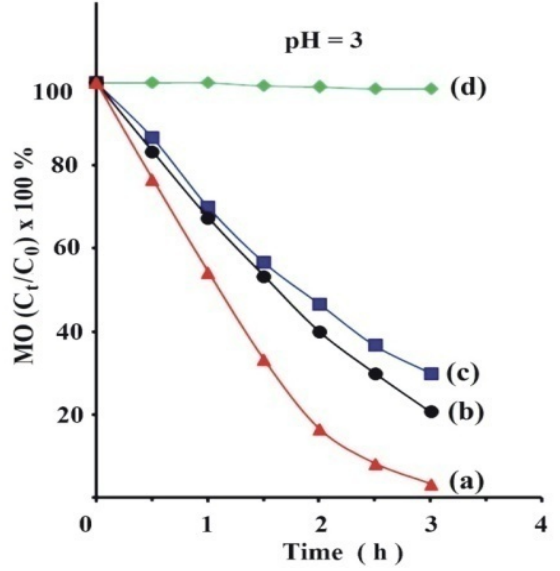

Figure 5. Degradation rate of $\mathrm{MO}$ dye solution in the dark and in the presence of different photocatalyst under exposure to UV light at $\mathrm{pH}=3$ using (a). $\mathrm{TiO}_{2}-\mathrm{P} 25$, (b). $\mathrm{Fe}_{3} \mathrm{O}_{4} / \mathrm{ZnO}$ (Ald), (c). $\mathrm{Fe}_{3} \mathrm{O}_{4} / \mathrm{ZnO}(\mathrm{S})$ and (d). blank.

It has been reported by Álvarez et al. (2010), Apopei et al. (2014), and Xue et al. (2013) that $\mathrm{TiO}_{2}$ P25 has an excellent photoactivity for removal pollutants in pharmaceutical and personal care products, 4-Chlorophenol and pollutants in methyl orange from an aqueous solution. The high photo-catalytic activity of $\mathrm{TiO}_{2}$ P25 is probably due to finer crystallite size (20$25 \mathrm{~nm}$ ), and BET specific surface area $\sim 50 \mathrm{~m}^{2} . \mathrm{g}^{-1}$ (Salazar 2010). Further, $\mathrm{TiO}_{2} \mathrm{P} 25$ has unique crystal structure, which is composed of anatase

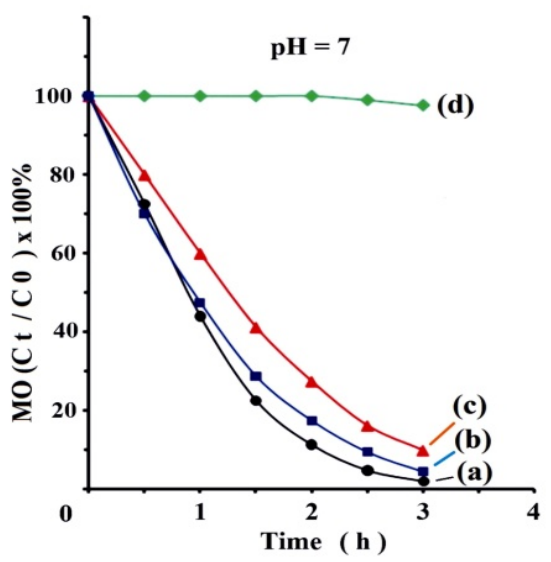

Figure 6. Degradation rate of MO dye solution in the dark and in the presence of different photo-catalyst under exposure to UV light at $\mathrm{pH}=7$ using (a). $\mathrm{Fe}_{3} \mathrm{O}_{4} / \mathrm{ZnO}$ (Ald), (b). $\mathrm{Fe}_{3} \mathrm{O}_{4} / \mathrm{ZnO}(\mathrm{S})$, (c). $\mathrm{TiO}_{2}-\mathrm{P} 25$ and (d). blank.

$(80 \%)$ and rutile $(20 \%)$. In spite of $\mathrm{TiO}_{2} \mathrm{P} 25$ remains the most widely used photo-catalyst in water treatment, the difficulty in the recovery of the catalyst because of its small size to search alternative materials. The decreased of photocatalytic activity of the $\mathrm{Fe}_{3} \mathrm{O}_{4} / \mathrm{ZnO}$ in acidic condition is most likely due to the photocorrosion of $\mathrm{ZnO}$. It has been reported that the zinc hydroxide surface $(\mathrm{Zn}-\mathrm{OH})$ can become charged by reacting with $\mathrm{H}^{+}$(acidic environment) or $\mathrm{OH}^{-}$(basic environment) ions due to surface amphoteric reactions (Abdollahi et al. 2012), Feng et al. 2014). 
In contrast, the photo-catalytic efficiency of commercial and synthesized $\mathrm{ZnO}$ in $\mathrm{Fe}_{3} \mathrm{O}_{4} / \mathrm{ZnO}$ $\mathrm{NCs}$ in acidic condition is less favourable. Based on the Table 1., the degradation of $\mathrm{MO}$ dye solution by $\mathrm{Fe}_{3} \mathrm{O}_{4} / \mathrm{ZnO}$ (Ald) and $\mathrm{Fe}_{3} \mathrm{O}_{4} / \mathrm{ZnO}$ (S) NCs is obtained about $80 \%$ and $70 \%$, respectively. The low of photo-catalytic efficiency of the $\mathrm{ZnO}$ in both samples $\mathrm{Fe}_{3} \mathrm{O}_{4} / \mathrm{ZnO}$ (Ald) and $\mathrm{Fe}_{3} \mathrm{O}_{4} / \mathrm{ZnO}(\mathrm{S}) \mathrm{NCs}$ can be attributed to the poor chemical stability of $\mathrm{Fe}_{3} \mathrm{O}_{4} / \mathrm{ZnO} \mathrm{NC}$ in acidic environment (Abdollahi et al. 2012; Wei et al. 2012). Figure 6 . shows the relationship between irradiation time and degradation rate of $\mathrm{MO}$ dye solution at $\mathrm{pH}=7$ treated by $\mathrm{Fe}_{3} \mathrm{O}_{4} / \mathrm{ZnO}(\mathrm{S})$, $\mathrm{Fe}_{3} \mathrm{O}_{4} / \mathrm{ZnO}$ (Ald), $\mathrm{TiO}_{2} \mathrm{P} 25$, and non-catalysts under UV light. Based on the Table 1., the degradation rate of $\mathrm{MO}$ dye solution is obtained of $99 \%$ for $\mathrm{Fe}_{3} \mathrm{O}_{4} / \mathrm{ZnO}$ (Ald) $\mathrm{NCs}, 96 \%$ for $\mathrm{Fe}_{3} \mathrm{O}_{4} / \mathrm{ZnO}$ (S) $\mathrm{NCs}$ with $0.1 \mathrm{~g} / 100 \mathrm{ml}$ ( $\left.1 \mathrm{~g} / \mathrm{L}\right)$ respectively, and $88 \%$ of $\mathrm{TiO}_{2} \mathrm{P} 25$ NPs. While the decolouration rate of the $\mathrm{MO}$ dyes without any catalysts is about $3 \%$. It is clear that at neutral condition $(\mathrm{pH}=7)$ the photo-catalytic activities of the $\mathrm{Fe}_{3} \mathrm{O}_{4} / \mathrm{ZnO}$ (Ald), and $\mathrm{Fe}_{3} \mathrm{O}_{4} / \mathrm{ZnO}$ (S) NCs show a better performance than that of $\mathrm{TiO}_{2}$ P25 after 180 minutes UV-irradiation.

In fact, the weight fraction of $\mathrm{ZnO}$ catalyst in the $\mathrm{Fe}_{3} \mathrm{O}_{4} / \mathrm{ZnO}$ (Ald) and $\mathrm{Fe}_{3} \mathrm{O}_{4} / \mathrm{ZnO}$ (S) NCs with $\mathrm{TiO}_{2}$ Degussa P25 NPs is the same. It is suggested that mechanical energy can induce growth of nanocrystals in $\mathrm{ZnO}$ powder and change their surface properties so that affect significantly the photocatalytic activities of $\mathrm{Fe}_{3} \mathrm{O}_{4} / \mathrm{ZnO} \mathrm{NCs}$ for methyl orange dye degradation in neutral condition. Beside that, the presence of magnetic $\mathrm{Fe}_{3} \mathrm{O}_{4} \mathrm{NPs}$ with high $\mathrm{M}_{\mathrm{s}}$ Value $\left(102 \mathrm{emu}^{-1} \mathrm{~g}^{-1}\right.$ ) as the core in the $\mathrm{ZnO}$ system shell provides additional surface active site for adsorption of organic pollutants in $\mathrm{MO}$ dyes solution. This is consistent with the results conducted by Nikazar et al. (2014). They used precipitation method for $\mathrm{Fe}_{3} \mathrm{O}_{4} / \mathrm{ZnO}$ preparation, followed with calcinations temperature of $550{ }^{\circ} \mathrm{C}$ during $2 \mathrm{~h}$ for phenol solution degradation after 5h UV-irradiation and produce high photocatalytic activity.

The high photo-catalytic performance $\mathrm{Fe}_{3} \mathrm{O}_{4} / \mathrm{ZnO} \mathrm{NCs}$ can be attributed to the different band gaps between $\mathrm{ZnO}\left(\mathrm{E}_{\mathrm{g}}=3.37 \mathrm{eV}\right)$ and $\mathrm{Fe}_{3} \mathrm{O}_{4}\left(\mathrm{E}_{\mathrm{g}}=0.1 \mathrm{eV}\right)$ and work function of $\mathrm{ZnO}$ and $\mathrm{Fe}_{3} \mathrm{O}_{4}$ which promote interfacial electron hole separation in the photo-catalytic process. The structural formula for magnetite is $\left[\mathrm{Fe}^{3+}\right] \mathrm{A} \quad\left[\mathrm{Fe}^{3+}, \mathrm{Fe}^{2+}\right] \mathrm{B} \quad \mathrm{O}_{4}$, this particular arrangement of cations on the $A$ and $B$ sub- lattice is called an inverse spinal structure (Ahadpour Shal and Jafari 2014). It has been reported that $\mathrm{Fe}^{3+}$ ions in $\mathrm{Fe}_{3} \mathrm{O}_{4}$ can act as photo-excited electron-trapping site to prevent the fast recombination photo-induced charge carriers, and also as a trigger for the enhanced photo-catalytic activity observed in $\mathrm{Fe}_{3} \mathrm{O}_{4}-\mathrm{TiO}_{2}$ in visible light (Feng et al. 2014; Xu and Li 2014). Further, the $\mathrm{Fe}^{2+}$ ions which are relatively unstable in comparison with $\mathrm{Fe}^{3+}$ ions, react with the oxygen dissolved in the reaction mixture to generate $\mathrm{Fe}^{3+}$ ions and ${ }^{*} \mathrm{O}_{2}^{-}$radicals. Thereby, it is obvious that the $\mathrm{Fe}_{3} \mathrm{O}_{4}$ magnetic core plays an important role in the photo-catalytic activity processes in the $\mathrm{Fe}_{3} \mathrm{O}_{4} / \mathrm{ZnO} \mathrm{NCs}$. Thus, the optimal photo-catalytic activity can be achieved only when the appropriate Fe content is added. Furthermore, due to the super-paramagnetic behaviour of $\mathrm{Fe}_{3} \mathrm{O}_{4}$, at least $0.085 \mathrm{~g}$ of the $\mathrm{Fe}_{3} \mathrm{O}_{4} / \mathrm{ZnO} \mathrm{NCs}$ can be easily collected from the original $0.1 \mathrm{~g}$ of $\mathrm{Fe}_{3} \mathrm{O}_{4} / \mathrm{ZnO}$.

The apparent first-order kinetic equation used to fit the experimental data was determined by equation (Wang, et al. 2012):

$$
-\ln \left(\frac{C_{t}}{C_{0}}\right)=K_{a p p .} \quad \mathrm{t} \quad \ldots \ldots
$$

Where $K_{a p p}$, is apparent rate constant, $C_{0}$ and $C_{t}$ represent the initial concentration and concentration at particular time, $t$ of $\mathrm{MO}$ dye solution. The half life $\left(t_{1 / 2}\right)$ is determined by equation (A. Fisli 2014):

$$
t_{1 / 2}=\ln 2 / K_{a p p}
$$

The corresponding linear transforms in In $\left(\mathrm{C}_{\mathrm{t}} / \mathrm{C}_{\mathrm{o}}\right)$ as a function of irradiation time are given in Fig. 7 and Fig. 8. At acidic environment $(\mathrm{pH}=$ 3), the $\mathrm{TiO}_{2} \mathrm{P} 25$ NPs decomposed the MO dye solution rapidly and completely in 180 minutes (Fig. 7). This phenomenon shows the highest photo-catalytic activity with the degradation rate constant $\left(K_{\text {app }}\right)$ obtained of 0.8732 hour $^{-1}$ and the half life $\left(t_{1 / 2}\right)$ is about 0.7938 hour, as seen in Table 1. It means that during $\mathbf{t}_{1 / 2}=0.7938$ hours ( $\sim 47 \mathrm{~min}$.$) , the pollutants in \mathrm{MO}$ dye solution decreased as much as $50 \%$ by $\mathrm{TiO}_{2} \mathrm{P} 25$ catalyst. In this condition $\mathrm{Fe}_{3} \mathrm{O}_{4} / \mathrm{ZnO}(\mathrm{S})$ dan $\mathrm{Fe}_{3} \mathrm{O}_{4} / \mathrm{ZnO}$ (Ald) NCs can degrade as much as $50 \%$ of pollutants in the dye $\mathrm{MO}$ in a longer time, during $\mathbf{t}_{1 / 2}=1.8861 \mathrm{~h}^{-1}$ (about 113 minutes) and $\mathbf{t}_{1 / 2}$ $=1.5211 \mathrm{~h}^{-1}$ (about 91 minutes), respectively as presented in Table 1. 


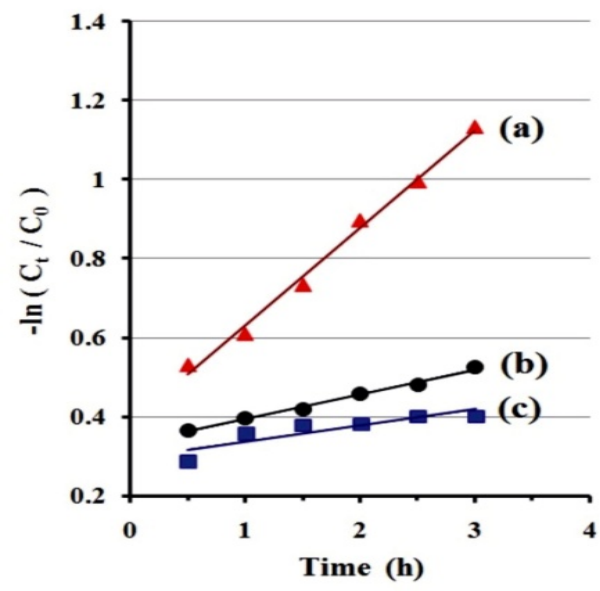

Figure 7. The kinetic curves of methyl orange dye disappearance for (a) $\mathrm{TiO}_{2} \mathrm{P} 25 \mathrm{NPs}$, (b) $\mathrm{Fe}_{3} \mathrm{O}_{4}$ I $\mathrm{ZnO}$ (Ald), and (c) $\mathrm{Fe}_{3} \mathrm{O}_{4} / \mathrm{ZnO}$ (S) $\mathrm{NCs}$ at $\mathrm{pH}=3$

However, at $\mathrm{pH}=7$ the reaction rate of $\mathrm{Fe}_{3} \mathrm{O}_{4} / \mathrm{ZnO}\left(\mathrm{S}\right.$ ) and $\mathrm{Fe}_{3} \mathrm{O}_{4} / \mathrm{ZnO}$ (Ald) NCs can degrade the $\mathrm{MO}$ dye solution completely up to 96\% (Fig. 8b) and 99\% (Fig. 8c), respectively in 180 minutes. The degradation rate constant $\left(K_{\text {app }}\right)$ is achieved of 1.0337 hour $^{-1}$, and 1.1485 hour ${ }^{-1}$ for $\mathrm{Fe}_{3} \mathrm{O}_{4} / \mathrm{ZnO}\left(\mathrm{S}\right.$ ) and $\mathrm{Fe}_{3} \mathrm{O}_{4} / \mathrm{ZnO}$ (Ald) NCs, respectively. The half life $\left(t_{1 / 2}\right)$ was obtained of $\mathbf{t}_{1 / 2}=0.6705(\sim 47$ minutes $)$ and $\mathbf{t}_{1 / 2}=0.5315$ hours ( 30 minutes) for $\mathrm{Fe}_{3} \mathrm{O}_{4} / \mathrm{ZnO}$ (S) and $\mathrm{Fe}_{3} \mathrm{O}_{4} / \mathrm{ZnO}$ (Ald) NCs, respectively. This means that, the $\mathrm{Fe}_{3} \mathrm{O}_{4} / \mathrm{ZnO}$ (Ald) $\mathrm{NC}$ can degrade the pollutants as much as $50 \%$ in $\mathrm{MO}$ dye solution is faster than the $\mathrm{Fe}_{3} \mathrm{O}_{4} / \mathrm{ZnO}(\mathrm{S}) \mathrm{NC}$ and $\mathrm{TiO}_{2} \mathrm{P} 25$ catalyst.

Based on the Figure $8 \mathrm{a}$ and $8 \mathrm{~b}$, we can obtain the same half life $\left(\mathbf{t}_{1 / 2}\right)$ for degradation process by $\mathrm{TiO}_{2} \mathrm{P} 25$ catalist (Fig. 8a) and the $\mathrm{Fe}_{3} \mathrm{O}_{4} / \mathrm{ZnO}$ (S) NC (Fig. 8b). The values are $\mathrm{t}_{1 / 2}=$ 0.6700 hour and $\mathrm{t}_{1 / 2}=0.6705 \mathrm{~h}(\sim 47 \mathrm{~min})$ for the degradation of the $\mathrm{MO}$ dye solution by $\mathrm{TiO}_{2} \mathrm{P} 25$ catalyst and the $\mathrm{Fe}_{3} \mathrm{O}_{4} / \mathrm{ZnO}(\mathrm{S}) \mathrm{NC}$, respectively under UV light, see Table 1 . The results show that their reaction rates are almost the same under UV-irradiation. Evidently, the degradation of MO dye solution decreases rapidly with increasing the reaction time which is indicated of the $\mathrm{MO}$ dye reduction from coloured aqueous to colourless.

\section{CONCLUSION}

It can be concluded high energy milling (HEM) process has been successfully prepared the $\mathrm{Fe}_{3} \mathrm{O}_{4} / \mathrm{ZnO}$ magnetic composites. The magnetic $\mathrm{Fe}_{3} \mathrm{O}_{4}$ was encapsulated with $\mathrm{ZnO}$ assynthesized and the $\mathrm{ZnO}$ commercial (Sigma

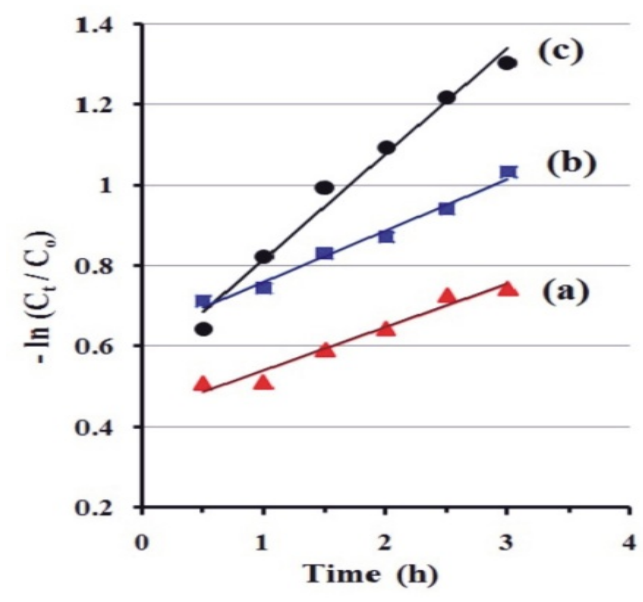

Figure 8. The kinetic curves of methyl orange dye disappearance for (a) $\mathrm{TiO}_{2} \quad \mathrm{P} 25$ NPs, (b) $\mathrm{Fe}_{3} \mathrm{O}_{4} / \mathrm{ZnO}(\mathrm{S})$, and (c) $\mathrm{Fe}_{3} \mathrm{O}_{4} / \mathrm{ZnO}$ (Ald) NCs at $\mathrm{pH}=7$.

Aldrich). XRD refinement result and TEM image interpreted that $\mathrm{ZnO}$ coated $\mathrm{Fe}_{3} \mathrm{O}_{4}$ are formed. TEM images indicate that the average particle size of aggregated $\mathrm{Fe}_{3} \mathrm{O}_{4} \mathrm{NP}$ about $15 \mathrm{~nm}$, and the thickness of the $\mathrm{ZnO}$ shell in both of $\mathrm{Fe}_{3} \mathrm{O}_{4} / \mathrm{ZnO}$ (Ald) and $\mathrm{Fe}_{3} \mathrm{O}_{4} / \mathrm{ZnO}$ (S) NCs is between 20-50nm. The VSM measurement show that the $\mathrm{Fe}_{3} \mathrm{O}_{4} \mathrm{NP}, \mathrm{Fe}_{3} \mathrm{O}_{4} / \mathrm{ZnO}$ (Ald) and $\mathrm{Fe}_{3} \mathrm{O}_{4} / \mathrm{ZnO}$ (S) NCs possess superparamagnetic behaviour, with magnetic saturation $\left(\mathrm{M}_{\mathrm{s}}\right)$ value are 102emu. $\mathrm{g}^{-1}, 28 \mathrm{emu} \cdot \mathrm{g}^{-1}$, and $26 \mathrm{emu} . \mathrm{g}^{-1}$, respectively.

Under acidic condition $(\mathrm{pH} \leq 3), \mathrm{TiO}_{2} \mathrm{P} 25$ can degrade the MO dye solution up to $96 \%$ higher when compared to $\mathrm{Fe}_{3} \mathrm{O}_{4} / \mathrm{ZnO}$ (Ald) and $\mathrm{Fe}_{3} \mathrm{O}_{4} / \mathrm{ZnO}$ (S) NCs. However, the photocatalytic activities of both $\mathrm{Fe}_{3} \mathrm{O}_{4} / \mathrm{ZnO}(\mathrm{S})$ and $\mathrm{Fe}_{3} \mathrm{O}_{4} / \mathrm{ZnO}$ (Ald) NCs appear to the most effective for removal of $\mathrm{MO}$ dye solution at neutral environment $(\mathrm{pH}=7)$. In this condition, the mechanical energy can induce the growth of nanocrystals in zinc oxide powder, and change their surface properties. As a result, they can remove almost of the pollutants in the methyl orange (MO) dye solution. Furthermore, the $\mathrm{Fe}_{3} \mathrm{O}_{4} / \mathrm{ZnO} \mathrm{NCs}$ can be easily collected and separated from the solution after the treatment process using a magnetic bar.

\section{ACKNOWLEDGEMENT}

This research was supported by "Research and Development of Smart magnetic and Magnetic Oxide Programme for DIPA Grants 2016" at Centre for Science and Technology of Advanced Materials - National Nuclear Energy Agency, Republic of Indonesia. 


\section{REFERENCES}

Abdollahi, Y., A.I H. Abdullah, Z. Zainal, and N. A. Yusof. 2012. Photocatalytic Degradation of P-Cresol by Zinc Oxide under UV Irradiation. International Journal of Molecular Sciences 13 (1): 302-15. doi:10.3390/ijms13010302.

Ahadpour S., Alireza, and A. Jafari. 2014. Study of Structural and Magnetic Properties of Superparamagnetic $\mathrm{Fe}_{3} \mathrm{O}_{4}-\mathrm{ZnO}$ Core-Shell Nanoparticles. Journal of Superconductivity and Novel Magnetism 27 (6): 1531-38. doi:10.1007/s10948-013-2469-9.

Álvarez, P. M., J. Jaramillo, F. López-Piñero, and P. K. Plucinski. 2010. Preparation and Characterization of Magnetic $\mathrm{TiO}_{2}$ Nanoparticles and Their Utilization for the Degradation of Emerging Pollutants in Water. Applied Catalysis $B$ : Environmental 100 (1-2): 338-45. doi:10.1016/j.apcatb.2010.08.010.

Apopei, P., C. Catrinescu, C. Teodosiu, and S. Royer. 2014. Mixed-Phase $\mathrm{TiO}_{2}$ Photocatalysts: Crystalline Phase Isolation and Reconstruction, Characterization and Photocatalytic Activity in the Oxidation of 4Chlorophenol from Aqueous Effluents. Applied Catalysis B: Environmental 160-161 (1). Elsevier B.V.: 374-82. doi:10.1016/j.apcatb.2014.05.030.

Choi, K.H, W.S Chae, E.M Kim, J.H Jun, and Y.R Kim. 2011. A Facile Fabrication of $\mathrm{Fe}_{3} \mathrm{O}_{4} / \mathrm{ZnO}$ Core-Shell Submicron Particles With Controlled Size. IEEE TRANSACTIONS ON MAGNETICS, VOL. 47, NO. 10, OCTOBER 47 (10): $1-4$.

Feng, X., H. Guo, K. Patel, H. Zhou, and Xia Lou. 2014. High Performance, Recovable $\mathrm{Fe}_{3} \mathrm{O}_{4}-\mathrm{ZnO}$ Nanoparticles for Enhanced Photocatalytic Degradation of Phenol. Chemical Engineering Journal 244: 327-34.

Fisli. A. 2014. The Development of $\left(\mathrm{Fe}_{3} \mathrm{O}_{4} / \mathrm{SiO}_{2} / \mathrm{TiO}_{2}\right) \quad$ Magnetic Photocatalyst for Elimination of Organic Substances (Methylene Blue and Paraquat) in Water, Ph. D. Thesis, at The Graduate Program University of Indonesia, Indonesia. Ph.D. Thesis.

Giwa, A., P. O. Nkeonye, K. A. Bello, and K. A. Kolawole. 2012. Photocatalytic Decolorization and Degradation of C. I. Basic Blue 41 Using $\mathrm{TiO}_{2}$ Nanoparticles. Journal of Environmental Protection. 3: 1063-69.
Iwasaki, T., K. Kosaka, S. Watano, T. Yanagida, and T. Kawai. 2010. Novel Environmentally Friendly Synthesis of Superparamagnetic Magnetite Nanoparticles Using Mechanochemical Effect. Materials Research Bulletin 45 (4):481-85. doi:10.1016/j.materresbull.2009.11.006

Larson, A. C., and R.B. Von Dreele. 2004. General Structure Analysis System (GSAS), Los Alamos National Laboratory Report LAUR (2004), Pp. 86-748

Nikazar, M., M. Alizadeh, R. Lalavi, and M. Rostami. 2014. The Optimum Conditions for Synthesis of $\mathrm{Fe}_{3} \mathrm{O}_{4} / \mathrm{ZnO}$ Core/shell Magnetic Nanoparticles for Photodegradation of Phenol. Journal of Environmental Health Science and Engineering $12 \quad(1)$ : 12-21. doi:10.1186/2052-336X-12-21.

Salazar, M.J.G. 2010. Development and Application of Titanium Dioxide Coated Magnetic Particles for Photocatalytic Oxidation of Aqueous Phase Organic Pollutants.

Wang, Z., L. Shen, and S. Zhu. 2012. Synthesis of Core-Shell $\mathrm{Fe}_{3} \mathrm{O}_{4}-\mathrm{SiO} 2-\mathrm{TiO} 2$ Microspheres and Their Application as Recyclable Photocatalysts. International Journal of Photoenergy 2012. doi:10.1155/2012/202519.

Wei, Y., B. Han, X. Hu, Y. Lin, X. Wang, and X. Deng. 2012. Synthesis of $\mathrm{Fe}_{3} \mathrm{O}_{4}$ Nanoparticles and Their Magnetic Properties. Procedia Engineering 27: 632-37.

Winatapura, D.S, S.H. Dewi, and W. A. Adi. 2016. Synthesis, Characterization, and Photocatalitic Activity of $\mathrm{Fe}_{3} \mathrm{O}_{4}-\mathrm{ZnO}$ Nanocomposite. International Journal of Technology ( 7 (3): 408-16.

Winatapura, Dewi S. H, and Ridwan. 2014. Synthesis and Characterization of $\mathrm{Fe}_{3} \mathrm{O}_{4}-\mathrm{ZnO}$ Composite through Precipitation Method. Journal of Waste Management Technology 17 (1): 7177.

Xu, M.g, and C. Li. 2014. Monodisperse Nanostructured of $\mathrm{Fe}_{3} \mathrm{O}_{4} / \mathrm{ZnO}$ Microrods Using for Waste Water Treatment. Advanced Powder Technology 25: 1-9.

Xue, C., Q. Zhang, J. Li, X. Chou, W. Zhang, H. Ye, Z. Cui, and P. J Dobson. 2013. High Photocatalytic Activity of $\mathrm{Fe}_{3} \mathrm{O}_{4}-$ $\mathrm{SiO}_{2}-\mathrm{TiO}_{2}$ Functional Particles with Core-Shell Structure. Journal of Nanomaterials 2013: 1-9. 